УДК 021

DOI $10.17223 / 22220836 / 17 / 5$

\title{
А.Р. Бикбулатова
}

\section{БИБЛИОТЕКАРЬ ХХІ В.: ПРОБЛЕМА ТРАНСФОРМАЦИИ}

\begin{abstract}
В конце XX в.библиотека вступает в новый сложный период своего развития, связанный как с инновационными сочиально-экономическими, культурными и технологическими изменениями в обществе, так и с внутренними динамическими прочессами в организачии самой библиотеки. В статье рассматриваются противоречия трансформации профессии библиотекаря в условиях инновационного, технологического, культурного развития сочиума и возможные пути решения данной проблемы. Охарактеризовано расиирение функиий библиотеки в XXI в.

Ключевые слова: трансформация, библиотекарь, профессиональная компетентность, инновация, квалификация.
\end{abstract}

Трансформация - это процесс, в результате которого проявляются признаки, не востребованные до определенного времени. Важно отметить, что в трансформации сущность не меняется, она только по-другому выражается, актуализируется, иначе объект трансформации разрушается и перестает быть таковым. В этом-то и проблема: трансформация не должна быть деструктивной, она должна помочь объекту по-новому проявиться, выжить и, изменяясь, укрепить свое место в картине мира. Под воздействием внешних и внутренних факторов трансформации подвергаются сложные, многоуровневые, динамические системы, к примеру система культуры, способная видоизменяться, адаптироваться и развиваться. В системе культуры библиотека занимает особое место, с одной стороны, она является меморативным объектом, способным сохранить, систематизировать знания предыдущих поколений, с другой стороны, библиотека - активный субъект продвижения культуры, требующий особой стратегии управления культурными изменениями.

Являясь социокультурным институтом, библиотека была создана для выполнения следующих действий, предусмотренных ее назначением: сбор, обработка, хранение, предоставление во временное пользование читателям произведений письменности и печати. Кроме собственно библиотечных функций, библиотека выполняет социальные функции, которые исторически обусловлены. Как отмечает Н.Е. Добрынина: «В разные периоды истории менялось социальное предназначение библиотеки, что определяло требования к библиотекарю и формировало его профессиональный и гражданский облик» [1. С. 237]. В конце XX в. библиотека вступает в новый сложный период своего развития, связанный как с инновационными социальноэкономическими, культурными и технологическими изменениями в обществе, так и с внутренними динамическими процессами в организации самой библиотеки. На сегодняшний день перспективной становится коммуникативная функция библиотек, подразумевающая различные форматы налаживания диалогов с читателями. Но перевес устной коммуникации в ущерб работе с библиотечными фондами может привести к превращению библиотеки в клубное учреждение. Подстраиваясь под предпочтения массовой культуры 
(визуальность, комфортность, доступность, мозаичность), библиотека старается стать «своей» в этом современном мире, открыться потенциальным пользователям, привлечь их внимание любыми культурными способами. Важно в этом процессе сохранить меру и не утратить сущность библиотеки. Но преобразить традиционный образ библиотеки и библиотекаря в сознании общественности с помощью грамотного формирования имиджа учреждения и профессии действительно необходимо.

Так каким быть библиотекарю в XXI в., чтобы не потеряться и не прятаться за чуждым, делать свое дело достойно и смело? Культурная политика государства, национальные программы в поддержку продвижения чтения, изменение парадигмы высшего профессионального образования, ориентированность на профессиональную компетентность библиотекаря указывают на то, что профессия библиотекаря перспективна и востребована, но нужен библиотекарь новой формации, обладающий 41-й профессиональной компетенцией - креативный информационный навигатор и посредник в системе документальных коммуникаций, обладающий знаниями и умениями менеджера и маркетолога в области библиотечно-информационной деятельности, универсал, разбирающийся во многих полезных для библиотечного обслуживания областях знаний (психология, социология, политология, правоведение, педагогика и др.) [2. С. 12].

Работникам библиотеки требуется постоянно осваивать современные гуманитарные знания, учитывающие динамику рыночной экономики, инновационные процессы в сфере культуры. Укрепление профессионального образования, обеспечение профессиональной подготовки через различные формы реквалификации - переподготовку, повышение квалификации - являются важными составляющими библиотечной деятельности. От библиотекаря, прежде всего, требуются информационная грамотность и медиаобразованность, и все же его самоутверждение в современном информационном обществе может быть и другим. По мнению А.В. Соколова, вопреки дисфункции чтения, распространению массовых литературных предпочтений библиотека остается учреждением, способным осуществить социально-культурную миссию по приобщению к вечным ценностям философии, науки, искусства, литературы [3. С. 9]. Библиотекарь - это благородный проводник в мир великих людей прошлого. Интернет не может сегодня обеспечить все интеллектуальные запросы пользователей, поэтому без обращения к библиотечным фондам не обойтись.

Национальная библиотека имени Ахмет-Заки Валиди Республики Башкортостан пытается функционировать в новом качестве, сохраняя традиции и поощряя инновации в библиотечном деле. Национальная библиотека РБ является государственной, центральной, универсальной, научной, общедоступной библиотекой Республики Башкортостан, культурным центром республиканского значения, национальным хранилищем документов, республикан-ским центром научно-исследовательской работы в области библиотековедения, библиографоведения и книговедения. На сегодняшний день в структуре библиотеки 27 специализированных отделов и 2 самостоятельных сектора: Центр юношеского чтения и Центр детского чтения. Национальная библиотека РБ совместно с Министерством культуры РБ определяет 
республиканскую библиотечную политику во всех сферах библиотечноинформационной деятельности, в том числе и кадровой. Для оптимизации внутренних коммуникаций, собственно библиотечных функций, был создан Центр повышения квалификации специалистов, на базе которого проходят семинары, тренинги, курсы повышения квалификации для библиотекарей республики. Библиотека осуществляет выездные зональные семинары во все районы республики, поднимая актуальные проблемы модернизации библиотечноинформацион-ной деятельности. Национальная библиотека РБ также организовывает курсы повышения квалификации, в которых принимают участие ведущие теоретики и практики крупнейших российских библиотек и вузов.

Расширение функций учреждения потребовало привлечения в библиотеку специалистов из других областей знаний, увеличения поля сотрудничества с заинтересованными организациями. Пересмотр многообразия позиций деятельности библиотеки привел к созданию новых активных практик, проектов, социологических опросов и маркетинговых исследований. К примеру, Национальная библиотека РБ является основным партнёром детского клуба ТРК МЕГА. На базе Центра детского чтения успешно функционирует театр. Сотрудники отдела рукописей и редких изданий активно осуществляют сотрудничество с Институтом истории, языка и литературы УНЦ РАН. Библиотека носит имя выдающегося востоковеда и общественного деятеля, что обязывает вести работу по сбору, хранению, переводу, популяризации наследия великого ученого, проводить международные конференции, объединять научную общественность России, Узбекистана, Турции, Германии вокруг имени Ахмет-Заки Валиди.

Библиотекарь XXI в., трансформируясь, способен уверенно вписаться в ритм социального времени, в непрерывные инновации, так как условия для этого создаются на всех уровнях библиотечной системы России.

\section{Лuтература}

1. Добрынина Н.Е. Специалист библиотечного дела в контексте формирования образа библиотек XXI века // Библиотечное дело - XXI век: науч.-практ. сб. 2011. Вып. 2 (22). С. 236-249.

2. Федеральный государственный образовательный стандарт высшего профессионального образования по направлению подготовки 071900 - Библиотечно-информационная деятельность [Электронный ресурс] : квалификация (степень) Бакалавр / Министерство образования и науки Российской Федерации (М., 2010). URL: http://www.edu.ru/db/mo/Data/d_10/prm3-1.pdf (дата обращения: 29.12.2014).

3. Соколов А.B. Миссия и мутация библиотек: Раздумья интеллигента-книжника // Библиотечное дело. 2009. № 14. С. 2-10.

Bikbulatova Albina R. National library of the Republic of Bashkortostan named after Ahkmet Zaki Validi (Ufa, Russian Federation). E-mail: ar250973@mail.ru. DOI 10.17223/22220836/17/3

LIBRARIAN OF THE XXI CENTURY: THE PROBLEM OF TRANSFORMATION

Key words: transformation, librarian, professional competence, innovation, skills development.

Transformation is a process during which characteristics non-demanded before are detected. The essence of the object is not changed during transformation but it is actualized in other way; otherwise the object of transformation is destroyed. The problem is that transformation should not be destructive, during transformation the object should be presented in other way, it should survive and strengthen its position in the world view. The library plays a special role in the culture. On the one hand the library is a memorial object preserving knowledge of previous generations, on the other hand the library is an active subject of culture promotion. 
Being a social-cultural institution, library was founded for collection, processing, storage and provision for temporary use of works of literature and printed works. At the same time the library performs social functions which influence the creation of professional and civil image of the librarian. Due to the innovative changes in the society and internal dynamic processes in the organization of the library itself the end of the XX century was a very difficult period for librarians.

Cultural policy of the country, national programs aimed at promotion of reading, changes of the paradigm of higher professional education and professional competence orientation show prospectivity and importance of the profession of the librarian. But nowadays we need a librarian of a new formation - a creative informational navigator and mediator in the system of documentary communications, possessing knowledge and skills of the manager and marketing consultant in the field of informationallibrarian activity, universal professional knowing different useful for librarian activity fields of knowledge. Library personnel constantly need to learn modern humanitarian knowledge, update professional qualification and information literacy.

The National library of the Republic of Bashkortostan named after Ahkmet-Zaki Validi is trying to operate in a new capacity, preserving traditions and encouraging innovations in the librarian activity. The National library of the Republic of Bashkortostan in cooperation with the Ministry of culture of the Republic of Bashkortostan defines the republican librarian policy in all fields of librarianinformational activity, including HR management activities. For optimization of internal communications the Center of skills development for the specialists was founded. Here seminars, training courses, skills development courses for the librarians of the republic are carried out with the involvement of leading theoreticians and practitioners of the major Russian libraries and educational institutions of higher education. Expandability of the functions of the institution required to extend the field of cooperation with the interested organizations. Revision of the diversity of library activities led to the creation of new active practices, projects, sociological opinion polls and marketing researches. An active work is carried out in the field of collection, storage, translation, popularization of the works of the great scientist Akhmet-Zaki Validi after whom the National library of the Republic of Bashkortostan was named.

By transforming, a librarian of the XXI century can integrate into the modern rhythm of life, as the possibilities for this are provided at all levels of the librarian system of Russia.

\section{References}

1. Dobrynina N.E. Spetsialist bibliotechnogo dela $\mathrm{v}$ kontekste formirovaniya obraza bibliotek XXI veka [The librarian and the image of the library in the 21 st century]. Bibliotechnoe delo - XXI vek, 2011, iss. 2 (22), pp. 236-249.

2. The federal state educational standard of higher education, 071900 - Library and Information Activities. Bachelor's Degree. Ministry of Education and Science of the Russian Federation (Moscow, 2010). Available from: http://www.edu.ru/db/mo/Data/d_10/prm3-1.pdf. (Accessed: 29th December 2014). (In Russian).

3. Sokolov A.V. Missiya i mutatsiya bibliotek: Razdum'ya intelligenta-knizhnika [Mission and mutation of libraries: Thoughts of an intellectual who likes reading]. Bibliotechnoe delo, 2009, no. 14, pp. 2-10. 